Article

\title{
Construction of a Novel Three-Dimensional PEDOT/RVC Electrode Structure for Capacitive Deionization: Testing and Performance
}

\author{
Ali Aldalbahi ${ }^{1, *}$ (D), Mostafizur Rahaman ${ }^{1}$, Periyasami Govindasami ${ }^{1}$, Mohammed Almoiqli ${ }^{2}$, \\ Tariq Altalhi ${ }^{3}$ and Amine Mezni ${ }^{3,4}$ \\ 1 Department of Chemistry, College of Science, King Saud University, Riyadh 11451, Saudi Arabia; \\ mrahaman@ksu.edu.sa (M.R.); periyasamig@gmail.com (P.G.) \\ 2 Nuclear Sciences Research Institute, King Abdulaziz City for Science and Technology, Riyadh 12371, \\ Saudi Arabia; almoiqli@kacst.edu.sa \\ 3 Department of Chemistry, Faculty of Science, Taif University, Taif 21974, Saudi Arabia; \\ Ta.altalhi@tu.edu.sa (T.A.); amine.mezni@gmail.com (A.M.) \\ 4 Unite de recherche Synthese et Structure de Nanomateriaux UR11ES30, Faculte des Sciences de Bizerte, \\ Universite de Carthage, Jarzouna 7021, Tunisia \\ * Correspondence: aaldalbahi@ksu.edu.sa; Tel.: +966-114-697-526
}

Received: 31 May 2017; Accepted: 18 July 2017; Published: 24 July 2017

\begin{abstract}
This article discusses the deposition of different amount of microstuctured poly(3,4-ethylenedioxythiophene) (PEDOT) on reticulated vitreous carbon (RVC) by electrochemical method to prepare three-dimensional (3D) PEDOT/RVC electrodes aimed to be used in capacitive deionization (CDI) technology. A CDI unit cell has been constructed here in this study. The performance of CDI cell in the ion removal of $\mathrm{NaCl}$ onto the sites of PEDOT/RVC electrode has been systematically investigated in terms of flow-rate, applied electrical voltage, and increasing PEDOT loading on PEDOT/RVC electrodes. It is observed that the increase in flow-rate, electric voltage, and PEDOT loading up to a certain level improve the ion removal performance of electrode in the CDI cell. The result shows that these electrodes can be used effectively for desalination technology, as the electrosorption capacity/desalination performance of these electrodes is quite high compared to carbon materials. Moreover, the stability of the electrodes has been tested and it is reported that these electrodes are regenerative. The effect of increasing $\mathrm{NaCl}$ concentration on the electrosorption capacity has also been investigated for these electrodes. Finally, it has been shown that $1 \mathrm{~m}^{3}$ PEDOT-120 min/RVC electrodes from $75 \mathrm{mg} / \mathrm{L} \mathrm{NaCl}$ feed solution produce 421, 978 L water per day of $20 \mathrm{mg} / \mathrm{L} \mathrm{NaCl}$ final concentration.
\end{abstract}

Keywords: PEDOT/RVC composites; CDI technology; ion removal; electrosorption performance; CDI stability; water production

\section{Introduction}

Capacitive deionization (CDI) technology, which is also called electrosorption [1], is an electrochemical desalination tool [2-6]. It provides a simple and robust approach to the removal of trace ions from solution [5,7-9]. It generally follows the electric double layer theory [2]. The electrochemical double layer is formed at the electrodes and electrolyte solution interfaces on the application of a direct current. For more than half a century, it has been demonstrated that CDI technology has the potential to be an energy efficient desalination method because it is operated at low direct voltages (DV) (between 0.8 to 1.6 voltage) without high-pressure pumps and thermal heaters $[2,4-6,10,11]$.

A CDI cell consists of two electrodes that are placed face to face at both sides of a spacer, which allows for aqueous solution to stream through it. These electrodes can be called anode and cathode 
and can be made out of any material, not necessarily only metals [2]. Membrane is used as a separator between the two electrodes in a CDI cell to prevent an electrical short and to maintain a constant distance [12]. There are a number of different porous carbon materials that can be applied as electrodes in capacitive deionization (CDI), such as carbon felt [13], carbon aerogels [14], carbon cloth [5] and titania modified carbon cloth $[7,8]$. More recently, carbon nanotube structures $[9,15]$, carbon nanofiber [1] and inherently conducting polymers such as polypyrrole [16] have been investigated for this purpose. Carbon materials have been deemed good electrodes for CDI because of their easy accessibility, low cost, resistance to acidic and basic environments, low density, diverse porous structure, and other properties [17].

Reticulated vitreous carbon (RVC), which initially was designed as an acoustic isolator [18], was first developed as a thermally insulating, micro-porous glassy carbon electrode material [19]. It is described as a three-dimensional (3D) porous structure having a honeycomb or foamy structure. Friedrich et al. [20] presented an illustrated review of RVC as an electrode material, encompassing characteristics such as a very high area: volume ratio depending on porosity grade, a low density, a low thermal expansion, a high corrosion resistance, high thermal and high electrical conductivities that are very attractive for electrochemical applications [20,21]. Furthermore, RVC can easily be surface modified with various materials [22,23] including conducting polymers [24-28].

Poly(3,4-ethylenedioxythiophene) (PEDOT) has been regarded as a promising pseudo-capacitive material due to its fast charge-discharge kinetics and stores charge not only in the electrical double layer but also throughout the body of the polymer by rapid faradaic charge transfer. Therefore, many researchers have studied PEDOT as an electrode material for supercapacitors having high energy and power density [29-31]. It should be noted that PEDOT, reported in the PEDOT/carbon composite electrodes for supercapacitors, was synthesized in-situ on carbon materials by electrochemical or chemical-polymerization from EDOT [32]. The electrochemical deposition of conducting polymers on carbon substrates has been studied with the goal of improving the mechanical properties of these polymers [33-35].

The aim of the present research is to make PEDOT/RVC composites and use PEDOT as materials and 3D microstructure electrodes in CDI technology. RVC has been used as the substrate in a CDI system to reduce the resistance of solution flow through the electrode, increase the stability of composite electrode towards high flow-rate pressure, increase the possibility of ions reaching all electrode surfaces in a short time for electrosorption, and shorten the time of ions release from the electrode surface. An attempt has been made to improve the performance of the CDI system in terms of geometric volume and area by electrodeposition of different percentages of PEDOT on RVC electrodes. Moreover, a simple flow-through cell has been made and designed in such a manner that will direct solution flow between electrodes in a CDI system.

\section{Materials, Methods and Experimental}

\subsection{Chemicals and Materials}

Commercially available 3,4-ethylenedioxythiophene monomer (EDOT), having purity $99.9 \%$, has been procured from Sheng Chemical Ltd (Taichung, Taiwan). The chemicals, namely, acetonitrile $(\mathrm{ACN})$ (AR grade), lithium perchlorate $\left(\mathrm{LiClO}_{4}\right)$ (AR grade), concentrated nitric acid $(70 \%)$ and sodium chloride (AR grade) were purchased from Sigma-Aldrich (Darmstadt, Germany). The RVC (60 ppi (normal pores per linear inch)) was supplied by ERG Materials and Aerospace Engineering limited (Oakland, CA, USA). All these materials were used as received. The milli-Q water, used in all preparations, possesses a resistivity $18.2 \mathrm{~m} \Omega \mathrm{cm}^{-1}$.

\subsection{Pre-Treatment of the RVC Electrode}

All the RVC electrodes were cut according to dimension $4 \mathrm{~cm} \times 3.5 \mathrm{~cm} \times 0.3 \mathrm{~cm}$ (length $\times$ width $\times$ thickness) $\left(32.5 \mathrm{~cm}^{2}\right.$ or $\left.4.2 \mathrm{~cm}^{3}\right)$ from a block of RVC material. For removing impurities, these electrodes 
were soaked in $2 \mathrm{M} \mathrm{HNO}_{3}$ for $24 \mathrm{~h}$ [36]. Subsequently, these electrodes were washed thoroughly with distilled water for removing acid until the $\mathrm{pH}$ of the effluent became neutral. The organic impurities

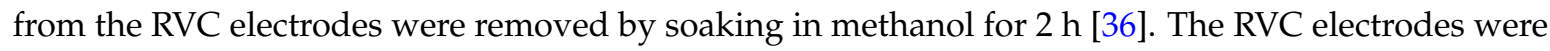
weighed after drying with nitrogen flow and keeping in an oven overnight at $110^{\circ} \mathrm{C}$.

\subsection{Electrochemical Polymerization of PEDOT on RVC Electrode}

In the present work, both cyclic voltammetric and chronoamperometry techniques were used to synthesize PEDOT/RVC composite electrodes, where, to ensure complete wetting, the RVC pieces were left in contact with working electrolyte for minimum $24 \mathrm{~h}$ before polymerization. The working electrodes were prepared by making electrical contact using a Pt wire hook. The reference and counter electrodes for electropolymerization were $\mathrm{Ag} / \mathrm{AgCl}(3 \mathrm{M} \mathrm{NaCl})$ electrode and a $\mathrm{Pt}$ mesh with dimension $4 \times 4 \mathrm{~cm}^{2}$, respectively. An organic electrolyte, used for electropolymerization, was acetonitrile solution that contains EDOT monomer $(0.01 \mathrm{M})$ and a supporting electrolyte salt $\mathrm{LiClO}_{4}(0.1 \mathrm{M})[37,38]$. Prior to electropolymerization, a thorough deoxygenation of the solution was carried out for $10 \mathrm{~min}$ at room temperature for all experiments. The deposition of PEDOT on RVC working electrode was done by cyclic voltammetry where three electrode systems were used in the applied voltage range $0-1.3 \mathrm{~V}$ at a scan rate $50 \mathrm{mV} / \mathrm{s}$. Moreover, the deposition of PEDOT film was performed galvanostatically on RVC electrode at a constant applied voltage for various time periods. The determination of PEDOT-ClO 4 quantity, coated on RVC, was done from the calculation of total charge passed during electropolymerization. The value of total charge was directly read from the I-V curve.

\subsection{Electrochemical Characterisation}

The capacitance was determined by cyclic voltammetry (CV). A PEDOT/RVC composite electrode was used as the working electrode (WE) in $1 \mathrm{M} \mathrm{NaCl}$ aqueous solution and scanned in the voltage range between -0.2 and $0.8 \mathrm{~V}$ using a three-electrode system; $\mathrm{RVC}$ electrode and $\mathrm{Ag} / \mathrm{AgCl}(3 \mathrm{M} \mathrm{NaCl})$ were used as counter electrode (CE) and reference electrode (RE), respectively. The benefit of using a reference electrode is that it has a stable and well-known electrode potential that measure the potential accurately. The scan rates ranging from 5 to $200 \mathrm{mV} / \mathrm{s}$. Contacts to the WE and CE were made using $\mathrm{Pt}$ wire. The experiments were conducted in batch mode. The volume of solution was $60 \mathrm{~mL}$.

\subsection{Measurement the Amount of Ion Removal from the $\mathrm{NaCl}$ Aqueous Solution}

$\mathrm{NaCl}$ concentration was determined in our laboratory by measuring the electrical conductivity of $\mathrm{NaCl}$ solution. The calibration curve linearity is shown in Figure S1 (see Supplementary Materials). Conductivity linearly increased as $\mathrm{NaCl}$ concentration increased. The equation from fitting a line starting from the origin $(0,0)$ to the calibration curve is as follows:

$$
\text { Cond }=1.9067 \times \text { Conc }
$$

where Cond and Conc are the conductivity $(\mu \mathrm{S} / \mathrm{cm})$ and concentration $(\mathrm{mg} / \mathrm{L})$ of $\mathrm{NaCl}$ solution, respectively. An example for calculation of the ion removal from $\mathrm{NaCl}$ solution has been shown in Supplementary Materials.

\section{Results and Discussion}

\subsection{Construction of a CDI Cell and Flow-through Open Cell Fabrication}

Capacitive deionization experiments were carried out in a flow-through system, depicted in Figure 1a. The CDI unit cell consisted of a flow-through cell which has two parallel electrodes that allows aqueous solution to stream between them, and the spacing of $5 \mathrm{~mm}$ between the electrodes is maintained. 
Lawrence Livermore National Laboratories in USA designed a CDI unit as a closed system to force water flow into all the pores of the electrodes [2]. It had a retaining plate, rubber gasket, electrode, rubber spacer and nylon spacer [9] and it was usually modified by researchers to make it suitable for their applications $[2,5,8,12,39-43]$.

A flow-through electrode was prepared for use in this CDI cell and this electrode has low hydraulic resistance. This means that water flow will easily pass through all the pores of the electrodes in a CDI flow-through cell, as shown in Figure 1b. This cell was designed in our laboratory and was built by printing on a Connex 350 3D printer, by Objet (Stratasys Ltd, Rheinmünster, Germany). This printer built our cell with UEROBACK material over a period of three hours. After that, it was washed with water in readiness for use in the CDI system. The cell production was basic, easy and fast, very accurate and resulted in a strong product. In this cell, we avoided using rubber gaskets, nut tool, threaded rods and insulator layer between electrodes. In addition, the electrical contact with electrodes was good and very easy. Furthermore, this cell has a rectangular external (Figure 1b) and H-like internal (Figure 1c) shapes. The dimensions of the outside cell was $57 \mathrm{~mm} \times 62 \mathrm{~mm} \times 32 \mathrm{~mm}$ in height, length and width, respectively. Each side had one $4 \mathrm{~mm}$ diameter hole for solution flow, one near the top and the other near the bottom. These holes are connected with $250 \mathrm{~mm}$ (MasterFlex L/S ${ }^{\circledR} 25$ ) pump (Cole-Parmer India Pvt. Ltd., Mumbai, India) tubing to a peristaltic pump in a recirculating fashion (Figure 1a). It is worth noting that the middle of both sides of the cell was fitted with $35 \mathrm{~mm} \times 35 \mathrm{~mm}$ glass windows to allow light to be directed through the cell to the electrodes. This was designed to be suitable for any future studies that need to use light for excitation of the electrodes. This glass was of dielectric material, transparent and allows all wavelengths to pass through it. Moreover, the $\mathrm{H}$-shape was designed inside the cell to be suitable for holding a glass conductivity electrode $(4 \mathrm{~mm}$ thickness) inside the cell if needed for any relevant applications. The dimensions inside the cell were $50 \mathrm{~mm} \times 50 \mathrm{~mm} \times 20 \mathrm{~mm}$ in height, length and width, respectively, as shown in Figure 1c (the top of the cell).

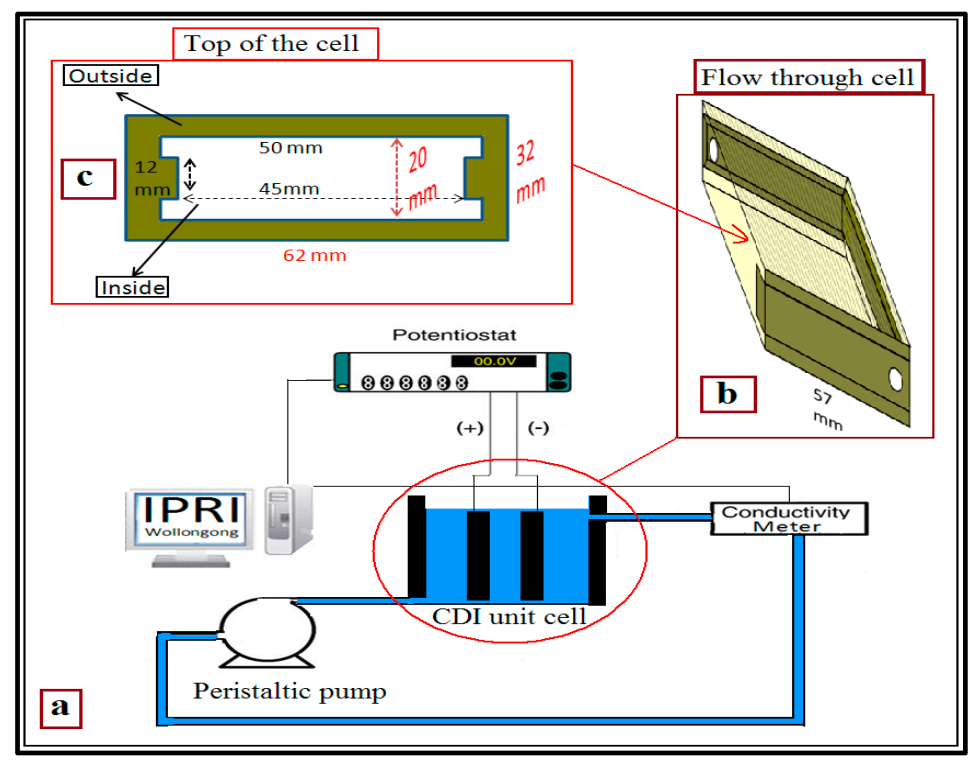

Figure 1. Schematic diagram of a capacitive deionization (CDI) cell (a) unit cell; (b) flow through cell; and (c) top of the cell.

\subsection{Effect of Working Conditions on Ion Removal Efficiency}

The key factors that affect the performance of ion removal of $\mathrm{NaCl}$ onto the sites of PEDOT/RVC composite electrode, that is, flow-rate and electrical voltage, were systematically investigated in this work. In this section, the charge processes (voltage applied) were carried out for $2.5 \mathrm{~min}$ with $60 \mathrm{~mL}$ of 
the $75 \mathrm{mg} / \mathrm{L} \mathrm{NaCl}$ solution $(143 \mu \mathrm{S} / \mathrm{cm})$ using a $\mathrm{RVC}$ electrode and $\mathrm{Ag} / \mathrm{AgCl}$ electrode as counter and reference electrodes, respectively, and the solution temperature was maintained at $293 \mathrm{~K}$.

\subsection{Effect of Applied Voltage on Ions Removal}

It is known that oppositely charged ions are attracted to oppositely charged electrodes and the adsorption behaviour of ion removal on the electrodes are affected by various direct electrical voltages applied [1]. To determine the greatest direct applied voltage that would be efficient in a CDI system, PEDOT-20 min/RVC composite electrode (which has $29 \mathrm{mg}$ PEDOT loading) was tested at four different applied voltages $(0.6,0.7,0.8$ and $0.9 \mathrm{~V})$ at a volume flow-rate of $35 \mathrm{~mL} / \mathrm{min}$ through a CDI cell (Figure 2a). The selection of these voltages was done according to our previous study published elsewhere [44]. Once the electric field was applied, the solution conductivity dropped dramatically because ions were attracted to the oppositely charged electrodes [1]. The CDI cell exhibited increased ions removal with increased applied voltage in the range of 0.6 to $0.8 \mathrm{~V}$. It was noticeable that the conductivity of $\mathrm{NaCl}$ solution decreased, once the electrode voltage was applied, to approximately $129.81,126.89$ and $123.41 \mu \mathrm{S} / \mathrm{cm}$ at $0.6,0.7$ and $0.8 \mathrm{~V}$, respectively. The CDI process was very efficient at $0.8 \mathrm{~V}$ because of enhanced electrostatic forces, with a much poorer performance at $0.6 \mathrm{~V}$. However, the conductivity change was not marked different at $0.9 \mathrm{~V}$ because the ions were adsorbed maximally at $0.8 \mathrm{~V}$ [1]. In the laboratory, when the electrical voltage was at $0.8 \mathrm{~V}$, no visible gas bubbles appeared in the target solution, indicating that there was no electrolysis of water taking place [45].

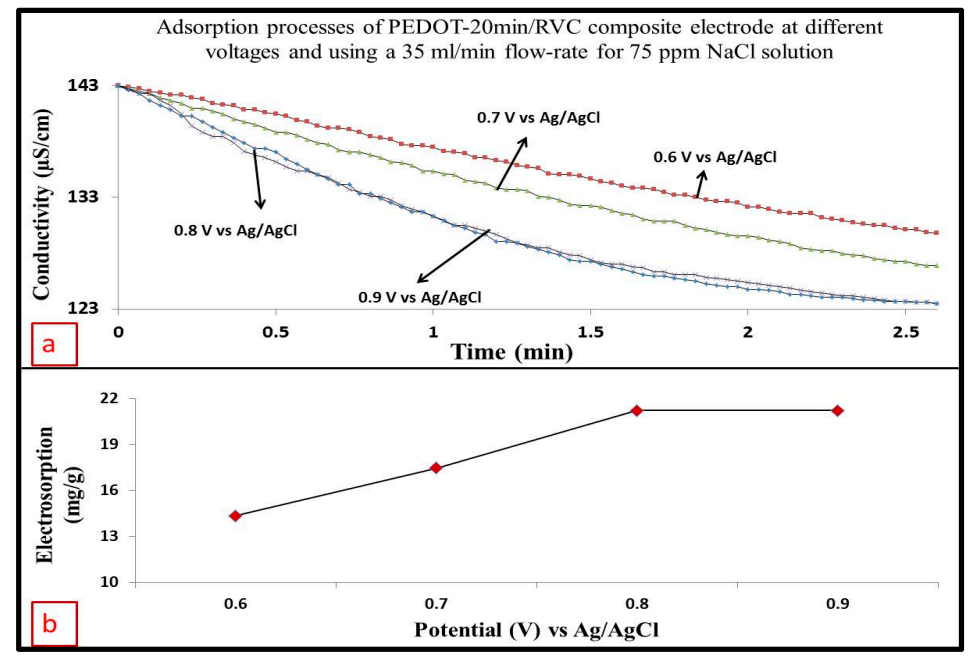

Figure 2. (a) Effect of applied voltage on electrosorption at a PEDOT-20 min/RVC composite electrode using a $35 \mathrm{~mL} / \mathrm{min}$ flow-rate and $75 \mathrm{mg} / \mathrm{L} \mathrm{NaCl}$ feed solution; (b) Plot of electrosorption capacity as a function of electrical voltage.

The electrosorption capacity of a PEDOT coating on RVC electrodes was calculated according to the following equations [45-47]:

$$
\begin{gathered}
M_{\text {mass }}=\left[\left(C_{0}-C_{f}\right) \times V\right] / m \\
M_{\text {volume }}=\left[\left(C_{0}-C_{f}\right) \times V\right] / Z \\
M_{\text {area }}=\left[\left(C_{0}-C_{f}\right) \times V\right] / A
\end{gathered}
$$

where $M_{\text {mass }}, M_{\text {volume, }}$ and $M_{\text {area }}$ are the electrosorption capacity of the working electrode in term of $\mathrm{mg} / \mathrm{g}, \mathrm{mg} / \mathrm{cm}^{3}$, and $\mathrm{mg} / \mathrm{cm}^{2}$, respectively. $C_{0}$ is the initial concentration of solution $(\mathrm{mg} / \mathrm{L}), C_{f}$ is the final concentration of solution (mg/L) after adsorption, $V$ is the volume of solution (L), $m$ is the mass of materials (g), and $Z$ and $A$ are volume of electrode and the geometric area, respectively. An example for calculating electrosorption capacity of PEDOT coated RVC is given in Supplementary Materials. It is 
seen that the electrosorption capacity, which has been calculated according to Equation (2) and shown in Figure $2 \mathrm{~b}$, gradually rose from 14.36 to $21.21 \mathrm{mg} / \mathrm{g}$. It is obvious that the electrosorption capacity is dependent on applied voltage, and higher ion removal is achieved with higher voltage. The high electrical voltage results in high electrosorption capacity because of strong Coulombic interaction between the electrode and charged $\mathrm{Na}^{+}$and $\mathrm{Cl}^{-}$ions $[9,48]$. However, the electrosorption capacity of the electrode at $0.9 \mathrm{~V}$ was exactly the same as the electrosorption capacity at $0.8 \mathrm{~V}$. Thus, the optimum working voltage for all PEDOT/RVC electrodes as electrosorption electrodes was ascertained to be $0.8 \mathrm{~V}$ and was selected for subsequent studies on the effect of flow-rate on ions removal in the CDI system; as reported in the next section.

\subsection{Effect of Flow-Rate on Ions Removal}

The effect of flow-rate on electrosorption performance of CDI was investigated using PEDOT-20 $\mathrm{min} /$ RVC composite electrode by testing at seven different flow-rates (Figure 3). It is clear from the figure that at a lower flow-rate, such as $15 \mathrm{~mL} / \mathrm{min}$, the solution has a high conductivity $130.22 \mu \mathrm{S} / \mathrm{cm}$ because too low a pump rate will introduce a low pump force that is lower than the electrosorption force and therefore decrease the electrosorption amount [45]. The $\mathrm{NaCl}$ conductivity decreased when the flow-rate was increased up to $80 \mathrm{~mL} / \mathrm{min}$, which had a conductivity of $116.20 \mu \mathrm{S} / \mathrm{cm}$ after $2.5 \mathrm{~min}$. This indicates accelerated adsorption of ions on the surface of the PEDOT/RVC electrode from the $\mathrm{NaCl}$ solution. However, it can be seen that the conductivity did not change significantly when the flow-rate was increased from $80 \mathrm{~mL} / \mathrm{min}$ up to $120 \mathrm{~mL} / \mathrm{min}$. This was due to the equilibrium between the electrostatic force of the electrode and the driving force in the flow-rate which did not significantly change when the flow-rate was increased. Hence, the results showed that $80 \mathrm{~mL} / \mathrm{min}$ was the optimum flow-rate.

Thus, methodical investigations have been done that demonstrated that an electrical voltage of $0.8 \mathrm{~V}$ and flow-rate of $80 \mathrm{~mL} / \mathrm{min}$ were the optimum conditions and key factors which affected the $\mathrm{NaCl}$ ion removal performance onto the sites of the PEDOT/RVC electrode. These conditions were then applied to investigate the effect of PEDOT loading on $\mathrm{NaCl}$ ion removal efficiency as reported in the next section.

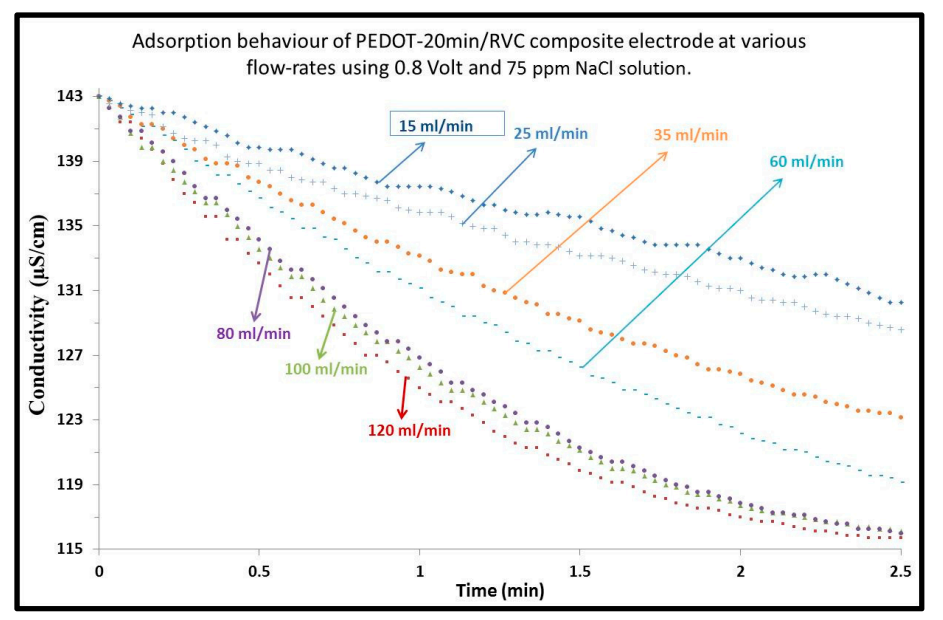

Figure 3. Effect of flow-rate on the electrosorption behaviour of PEDOT-20 $\mathrm{min} / \mathrm{RVC}$ composite electrode. Applied voltage: $0.8 \mathrm{~V}$; Concentration of $\mathrm{NaCl}$ feed solution: $75 \mathrm{mg} / \mathrm{L}$.

\subsection{Effect of PEDOT Loading of PEDOT/RVC Electrode on Ions Removal}

The CDI system was investigated with respect to the influence of increased loading of PEDOT into RVC electrodes on the ion removal performance (Figure 4). All experiments were performed with an electrical voltage of $0.8 \mathrm{~V}$ and a flow-rate of $80 \mathrm{~mL} / \mathrm{min}$ through the CDI system, using $60 \mathrm{~mL}$ 
of the $75 \mathrm{mg} / \mathrm{L} \mathrm{NaCl}$ solution, and solution temperature was maintained at $293 \mathrm{~K}$. The adsorption processes at first took $5 \mathrm{~min}$ and the drop in conductivity increased with increasing amounts of PEDOT into the RVC electrode. This indicates that the increase of the amount of PEDOT loading leads to increase in the interaction between the charged surface of the electrode and charged $\mathrm{Na}^{+}$ and $\mathrm{Cl}^{-}$ions. The conductivity would gradually approach a constant minimum level, indicating that saturation was achieved. Notably, the highest drop in conductivity was around $54.21 \mu \mathrm{S} / \mathrm{cm}$ using the PEDOT-120 min/RVC composite electrode. Furthermore, when the CDI system was under $0 \mathrm{~V}$ of applied voltage, the electrode can be quickly regenerated; that is, the adsorbed ions were desorbed from the electrodes due to the disappearance of electrostatic force. The discharge time was approximately $8 \mathrm{~min}$ to release all the ions from the electrodes and return the solution conductivity to its initial level. These results suggest that the CDI process using PEDOT coated RVC electrodes have a promise as an effective technology for desalination.

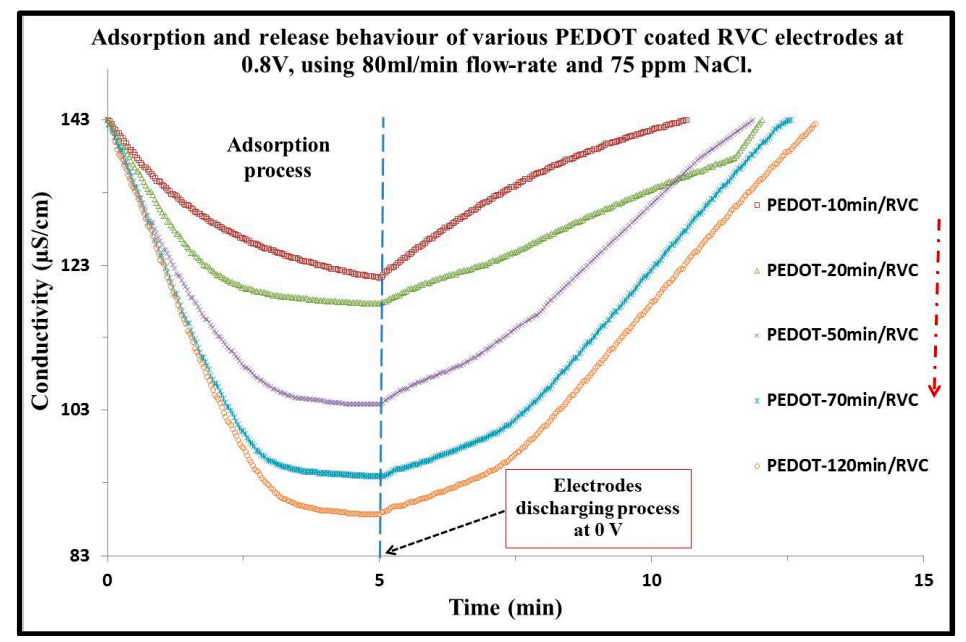

Figure 4. Effect of PEDOT loading of PEDOT/RVC electrode on ions removal efficiency using a CDI system. Applied voltage: $0.8 \mathrm{~V}$; NaCl feed solution concentration: $75 \mathrm{mg} / \mathrm{L}$; Flow-rate: $80 \mathrm{~mL} / \mathrm{min}$.

\subsection{Electrosorption Performance of PEDOT Coated RVC Electrode}

This section calculates the electrosorption capacity of all electrodes mentioned earlier. The mass of PEDOT in the RVC electrodes, which have $4.2 \mathrm{~cm}^{3}$ geometric volumes and $32.5 \mathrm{~cm}^{2}$ geometric areas, are 13, 29, 71, 117 and $240 \mathrm{mg}$, respectively (as described in our previous publication [15]). The variation of solution conductivity was monitored using a multi-function conductivity meter. Accordingly, the correlation between conductivity $(\mu \mathrm{S} / \mathrm{cm})$ and concentration $(\mathrm{mg} / \mathrm{L})$ was calibrated prior to experiments (Equation (1)).

The electrosorption performance of all PEDOT coated RVC electrodes are shown in Figure 5. The electrosorption per gram decreased with increasing mass of PEDOT. Clearly, when the PEDOT-10 $\mathrm{min} /$ RVC electrode had $13 \mathrm{mg}$ of PEDOT, the electrosorption was $52.84 \mathrm{mg} / \mathrm{g}$, and when PEDOT-120 min/RVC electrode had $240 \mathrm{mg}$ of PEDOT, the electrosorption was $6.52 \mathrm{mg} / \mathrm{g}$ (using Equation (2)). As mentioned before, our aim focuses on increasing the performance of the electrode in terms of geometric volume and area. Therefore, the electrosorption capacity per unit geometric volume and geometric area were calculated using Equations (3) and (4), respectively, and are presented in Table $1 \mathrm{as} \mathrm{mg} / \mathrm{cm}^{3}$ and $\mathrm{mg} / \mathrm{cm}^{2}$, respectively. It is clear that, in these terms, electrosorption increased with increasing amounts of PEDOT on the RVC electrodes. When the PEDOT-10 $\mathrm{min} / \mathrm{RVC}$ electrode had $13 \mathrm{mg}$ of PEDOT, the electrosorption was $0.05 \mathrm{mg} / \mathrm{cm}^{2}$ or $0.16 \mathrm{mg} / \mathrm{cm}^{3}$, and when PEDOT-120 min/RVC electrode had $240 \mathrm{mg}$ of PEDOT, the electrosorption was $0.12 \mathrm{mg} / \mathrm{cm}^{2}$ or $0.41 \mathrm{mg} / \mathrm{cm}^{3}$. It is worth mentioning that the electrosorption capacity of PEDOT-56/RVC electrode $(6.52 \mathrm{mg} / \mathrm{g})$ has better desalination performance than carbon materials 
such as activated carbon $(1.42 \mathrm{mg} / \mathrm{g})$, activated carbon nanofiber $(4.64 \mathrm{mg} / \mathrm{g})$, carbon nanotube $(2.33 \mathrm{mg} / \mathrm{g})$, ordered mesoporous carbon $(0.54 \mathrm{mg} / \mathrm{g})$, composite carbon nanotubes with carbon nanofiber $(3.32 \mathrm{mg} / \mathrm{g})$, reduced graphite oxide $(3.23 \mathrm{mg} / \mathrm{g})$ and composite ordered mesoporous carbon with carbon nanotubes $(0.63 \mathrm{mg} / \mathrm{g})$ [15,39,48-51]. In summary, although the electrosorption performance of the PEDOT-10 $\mathrm{min} / \mathrm{RVC}$ electrode is the best in term of $\mathrm{mg} / \mathrm{g}$ of ion removal, it is the PEDOT-120 $\mathrm{min} / \mathrm{RVC}$ electrode that affords the best ion removal in term of geometric area or geometric volume of electrode; that is, it removes the most ions in electrode terms. This is advantageous when the size of the electrode becomes a major consideration in designing a CDI system.

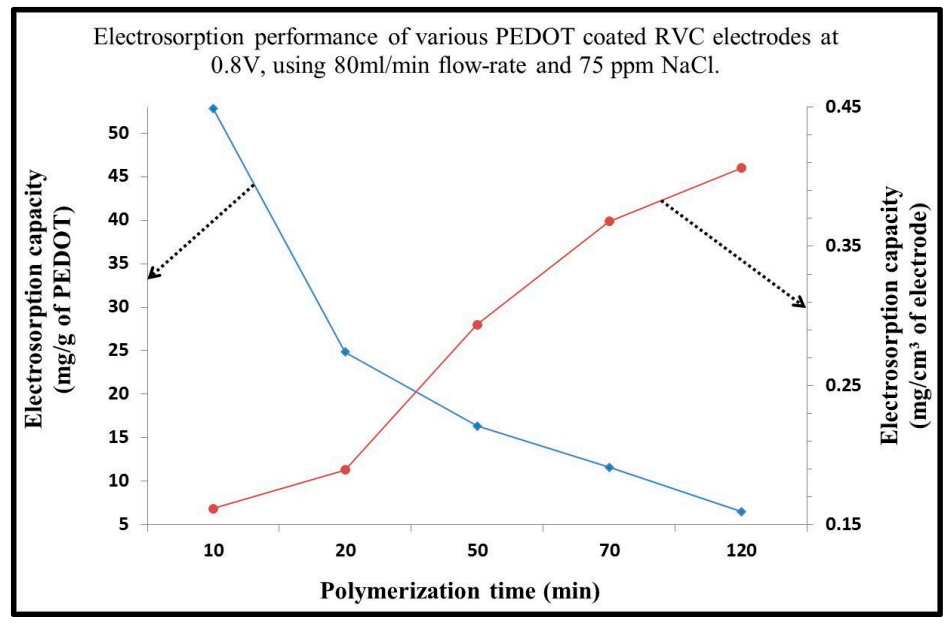

Figure 5. Effect of PEDOT loading of PEDOT/RVC electrodes on electrosorption as reported in terms of mass of PEDOT, and geometric volume of the PEDOT/RVC electrode.

Table 1. Electrosorption performance of PEDOT/RVC composite electrodes with different PEDOT loadings.

\begin{tabular}{cccc}
\hline \multirow{2}{*}{ PEDOT/RVC Composite Electrode } & \multicolumn{3}{c}{ Electrosorption Capacity } \\
\cline { 2 - 4 } & $\mathbf{m g} / \mathbf{g}$ of PEDOT & $\mathbf{m g} / \mathbf{c m}^{\mathbf{3}} \mathbf{~ o f ~ E l e c t r o d e ~}$ & $\mathbf{m g} / \mathbf{c m}^{\mathbf{2}}$ of Electrode \\
\hline PEDOT-10 $\mathrm{min} /$ RVC & 52.84 & 0.16 & 0.05 \\
PEDOT-20 min/RVC & 30.86 & 0.19 & 0.06 \\
PEDOT-50 min/RVC & 16.36 & 0.28 & 0.09 \\
PEDOT-70 $\mathrm{min} /$ RVC & 11.62 & 0.32 & 0.11 \\
PEDOT-120 $\mathrm{min} /$ RVC & 6.52 & 0.37 & 0.12 \\
\hline
\end{tabular}

\subsection{Stability}

Regeneration of PEDOT-120 min/RVC electrodes is a very important factor affecting their practical use in a CDI system. Figure 6 shows the electrosorption/regeneration cycles of PEDOT-120 min/RVC electrode, which was conducted by repeating several charging and regeneration cycles. When no oxidation and reduction reaction occurs in electrosorption, the current is mainly consumed for charging the electrode to electroadsorb ions from the bulk solution [52]. As can be seen, the polarization of the electrode at $0.8 \mathrm{~V}$ leads to a decrease of solution conductivity. The conductivity sharply decreased because ions migrate onto the oppositely charged surface, and then continues to gradually decrease until the electrical double layer is completely formed at the electrode/electrolyte interface [53]. Moreover, the regeneration can be achieved upon electrode depolarization at $0.0 \mathrm{~V}$. It can be noted that the process of regeneration can be carried out easily in a short time and the same pattern can be found in four repeated electrosorption-desorption cycles; each cycle takes $13 \mathrm{~min}$ : 5 min adsorption of ions and $8 \mathrm{~min}$ release of ions. In addition, the recycling stability was very high for the reason that the decay of electrosorption capacity has not been observed. It demonstrates that the electro-adsorbed ions 
can be desorbed by removing an electric field, and then the PEDOT-120 min/RVC electrode can be reused. Consequently, the electrosorption of ions using this electrode is a reversible process and that the amount of electro-adsorbed ions can be controlled, via manipulation of the electrical double layer formation at the electrode/electrolyte interface. The results show that the electrodes can specifically be used is desalination technology for seawater purification.

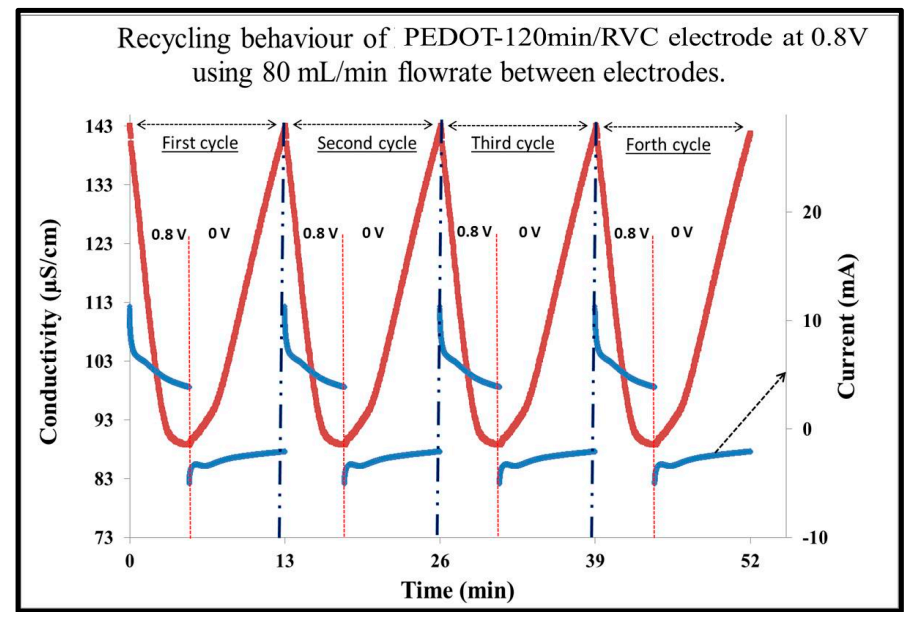

Figure 6. Multiple electrosorption-desorption and current response cycles for PEDOT-120 min/RVC electrode upon polarization and depolarization at 0.8 and $0.0 \mathrm{~V}$, respectively. $\mathrm{NaCl}$ feed solution concentration: $75 \mathrm{mg} / \mathrm{L}$.

\subsection{Effect of $\mathrm{NaCl}$ Concentration on Electrosorption Capacity}

In this section, the electrosorption behavior of PEDOT-120 min/RVC electrode in various $\mathrm{NaCl}$ concentrations, $25,50,75,100,200,300,400$ and $500 \mathrm{mg} / \mathrm{L}$ for one cycle desalination time (13 min), was investigated (Figure 7). This experiment was carried out at an electrical voltage of $0.8 \mathrm{~V}$ at a flow-rate of $80 \mathrm{~mL} / \mathrm{min}$ through a CDI cell. The amount of $\mathrm{NaCl}$ removed increases as the initial concentration is raised, which is due to the enhanced mass transfer rate of ions inside the micropores and reduced overlapping effect by higher concentration of solution [54-56]. The electrosorpition sharply increases at concentrations up to $100 \mathrm{mg} / \mathrm{L}$ and continues to increase up to $500 \mathrm{mg} / \mathrm{L}$. The electrosorption capacity of PEDOT-120 min/RVC electrde was 2.23, 4.31, 6.45, 8.58, 12.11, 14.41, 15.69 and $16.15 \mathrm{mg} / \mathrm{g}$ at $25,50,75,100,200,300,400$ and $500 \mathrm{mg} / \mathrm{L}$ of $\mathrm{NaCl}$ solution, respectively.

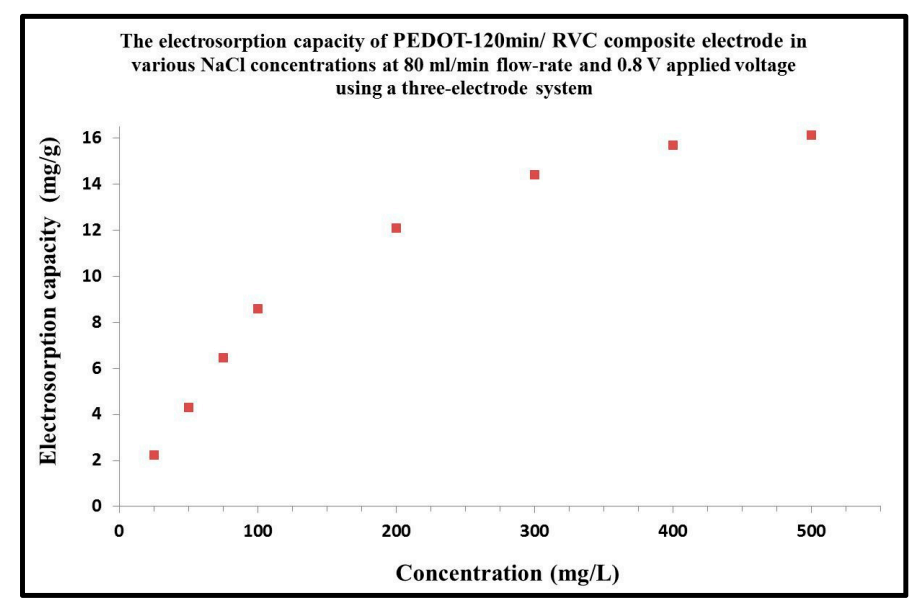

Figure 7. Electrosorption capacity of PEDOT-120 $\mathrm{min} / \mathrm{RVC}$ composite electrode at varous concentrations of $\mathrm{NaCl}$ feed solution. Applied voltage: $0.8 \mathrm{~V}$; Flow-rate: $80 \mathrm{~mL} / \mathrm{min}$. 


\subsection{Water Production by CDI System}

In this study, experiments were performed using a $75 \mathrm{mg} / \mathrm{L} \mathrm{NaCl}$ feed solution. Therefore, water production calculations are hereby based on this feed concentration. From the above mentioned discussion, it can be concluded that $1 \mathrm{~g}$ of PEDOT coated on $17.5 \mathrm{~cm}^{3}$ RVC electrode (PEDOT-120 $\mathrm{min} / \mathrm{RVC}$ composite electrode) adsorbed $6.45 \mathrm{mg} \mathrm{NaCl}$ during $13 \mathrm{~min}$ using initial concentration of solution $75 \mathrm{mg} / \mathrm{L}$ and the solution concentration after one desalination cycle became $68.55 \mathrm{mg} / \mathrm{L}$. In addition, the amount of salt electrosorbed will change with solution concentration, as shown by the relationship between the electrosorption capacity and solution concentration (Figure 7). Figure 7 also shows that the electrosorption capacity, however, appears to be linearly related to the $\mathrm{NaCl}$ concentration below $100 \mathrm{mg} / \mathrm{L}$ and this is confirmed by the straight line fit shown in Figure 8a, which affords Equation (5).

$$
\text { Electrosorption }(\mathrm{mg} / \mathrm{g})=0.086 \times \text { Concentration }
$$

From Equation (5), the concentration change after each desalination cycle will be known and this information can be used to obtain Figure $8 \mathrm{~b}$. Figure $8 \mathrm{~b}$ shows the concentration change after each desalination cycle to reach less than $1 \mathrm{mg} / \mathrm{L}$ using $1 \mathrm{~g}$ of PEDOT which is coated on $17.5 \mathrm{~cm}^{3}$ RVC electrode (PEDOT-120 min/RVC composite electrode). It is clear that the total desalination process requires 49 cycles to reduce the concentration of solution from $75 \mathrm{mg} / \mathrm{L}$ to less than $1 \mathrm{mg} / \mathrm{L}$. This means that water production employing this electrode needs $637 \mathrm{~min}$ (13 $\mathrm{min} \times 49$ cycles) to produce $1 \mathrm{~L}$ of water containing $\mathrm{NaCl}$ concentration of less than $1 \mathrm{mg} / \mathrm{L}$. Thus, the water produced per day is $2.26 \mathrm{~L}$ using $1 \mathrm{~g}$ PEDOT coated on $17.5 \mathrm{~cm}^{3} \mathrm{RVC}$ electrode or 129,176 L using $1 \mathrm{~m}^{3}$ of same composite electrode (PEDOT-120 min/RVC composite electrode). However, for low salt diet patients, a salt concentration not exceeding $20 \mathrm{mg} / \mathrm{L}$ is recommended. Therefore, if a salt concentration of 20 $\mathrm{mg} / \mathrm{L}$ is adopted as the goal, the water production will require 15 cycles that will require a total period of $195 \mathrm{~min}$. This will translate to a water production of 421,978 L using $1 \mathrm{~m}^{3}$ of PEDOT-120 min/RVC composite electrode.

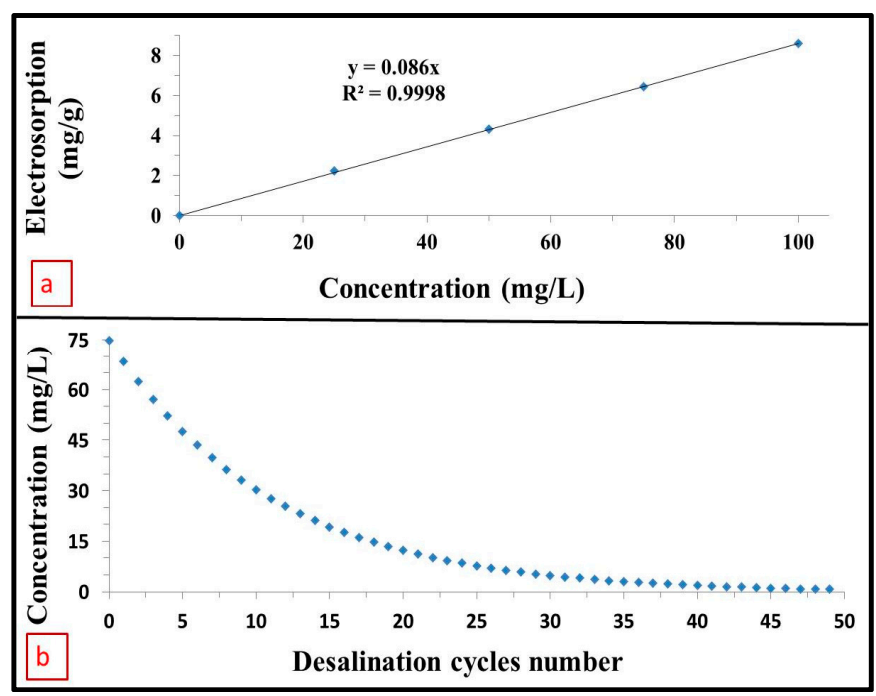

Figure 8. (a) Calibration curve of electrosorption vs. concentration of $\mathrm{NaCl}$ feed solution; (b) Concentration of feed solution vs. desalination cycles number for full desalination process to produce water of less than $1 \mathrm{mg} / \mathrm{L} \mathrm{NaCl}$ concentration.

\section{Conclusions}

In this study, PEDOT/RVC composite electrodes with varying amounts of PEDOT loadings were considered for application as 3D microstructure electrodes. PEDOT was successfully deposited by 
electropolymerization on RVC and used for the first time as materials and electrodes in CDI technology. It is seen that the removal of ions increases with the increase in applied voltage and flow rate up to a certain level and then become marginal. Moreover, the increase in amount of PEDOT loadings on PVC also increases the ions removal capability of the electrode. It has been demonstrated that the electrodes are regenerative. The electrosorption increases with the increase in concentration of $\mathrm{NaCl}$ solution. The aim of this study was achieved, as demonstrated by the improved performance of the CDI electrode in terms of unit geometric volume and geometric area. It was shown that they have better desalting performance compared to carbon materials. Furthermore, the water produced by $1 \mathrm{~m}^{3}$ PEDOT-120 $\mathrm{min} / \mathrm{RVC}$ electrodes from $75 \mathrm{mg} / \mathrm{L} \mathrm{NaCl}$ feed solution was calculated to be 421,978 L/day of water of $20 \mathrm{mg} / \mathrm{L} \mathrm{NaCl}$ final concentration.

Supplementary Materials: The following are available online at www.mdpi.com/1996-1944/10/7/847/s1, Figure S1: Calibration curve linearity for ionic conductivity vs. $\mathrm{NaCl}$ concentration.

Acknowledgments: The authors extend their appreciation to the Deanship of Scientific Research at King Saud University for funding this work through research group No. (RG-1436-005).

Author Contributions: Mohammed Almoiqli, Mostafizur Rahaman, Periyasami Govindasami and Ali Aldalbahi designed and performed the experiments, and analysed the data. Ali Aldalbahi, Tariq Altalhi and Amine Mezni also analysed the data and wrote the manuscript. All authors have read and approved the final manuscript.

Conflicts of Interest: The authors declare no conflict of interest.

\section{References}

1. Pan, L.; Wang, X.; Gao, Y.; Zhang, Y.; Chen, Y.; Sun, Z. Electrosorption of anions with carbon nanotube and nanofibre composite film electrodes. Desalination 2009, 244, 139-143. [CrossRef]

2. Welgemoed, T.J.; Schutte, C.F. Capacitive Deionization Technology(TM): An alternative desalination solution. Desalination 2005, 183, 327-340. [CrossRef]

3. Xu, P.; Drewes, J.; Heil, D.; Wang, G. Treatment of brackish produced water using carbon aerogel-based capacitive deionization technology. Water Res. 2008, 42, 2605-2617. [CrossRef] [PubMed]

4. Ahn, H.-J.; Lee, J.-H.; Jeong, Y.; Lee, J.-H.; Chi, C.-S.; Oh, H.-J. Nanostructured carbon cloth electrode for desalination from aqueous solutions. Mater. Sci. Eng. A 2007, 449-451, 841-845. [CrossRef]

5. Oh, H.-J.; Lee, J.-H.; Ahn, H.-J.; Jeong, Y.; Kim, Y.-J.; Chi, C.-S. Nanoporous activated carbon cloth for capacitive deionization of aqueous solution. Thin Solid Films 2006, 515, 220-225. [CrossRef]

6. Park, K.-K.; Lee, J.; Park, P.; Yoon, S.; Moon, J.; Eum, H.; Lee, C. Development of a carbon sheet electrode for electrosorption desalination. Desalination 2007, 206, 86-91. [CrossRef]

7. Ryoo, M.; Kim, J.; Seo, G. Role of titania incorporated on activated carbon cloth for capacitive deionization of $\mathrm{NaCl}$ solution. J. Colloid Interface Sci. 2003, 264, 414-419. [CrossRef]

8. Ryoo, M.; Seo, G. Improvement in capacitive deionization function of activated carbon cloth by titania modification. Water Res. 2003, 37, 1527-1534. [CrossRef]

9. Sfeir, M.; Beetz, T.; Wang, F.; Huang, L.; Huang, H.; Huang, M.; Hone, J.; Obrien, S.; Misewich, J.; Heinz, T.; et al. Optical Spectroscopy of Individual Single-Walled Carbon Nanotubes of Defined Chiral Structure. Science 2006, 312, 554-556. [CrossRef] [PubMed]

10. Lee, J.-B.; Park, K.-K.; Eum, H.-M.; Lee, C.-W. Desalination of a thermal power plant wastewater by membrane capacitive deionization. Desalination 2006, 196, 125-134. [CrossRef]

11. Kim, Y.; Hur, J.; Bae, W.; Choi, J. Desalination of brackish water containing oil compound by capacitive deionization process. Desalination 2010, 253, 119-123. [CrossRef]

12. Yang, C.-M.; Choi, W.-H.; Na, B.-K.; Cho, B.W.; Cho, W.I. Capacitive deionization of NaCl solution with carbon aerogel-silicagel composite electrodes. Desalination 2005, 174, 125-133. [CrossRef]

13. Conway, B.E.; Ayranci, E.; Al-Maznai, H. Use of quasi-3-dimensional porous electrodes for adsorption and electrocatalytic removal of impurities from waste-waters. Electrochim. Acta 2001, 47, 705-718. [CrossRef]

14. Gabelich, C.J.; Tran, T.D.; Suffet, I.H. Electrosorption of inorganic salts from aqueous solution using carbon aerogels. Environ. Sci. Technol. 2002, 36, 3010-3019. [CrossRef] [PubMed] 
15. Wang, X.Z.; Li, M.G.; Chen, Y.W.; Cheng, R.M.; Huang, S.M.; Pan, L.K.; Sun, Z. Electrosorption of ions from aqueous solutions with carbon nanotubes and nanofibers composite film electrodes. Appl. Phys. Lett. 2006, 89, 053127. [CrossRef]

16. Kim, B.C.; Ko, J.M.; Wallace, G.G. A novel capacitor material based on Nafion-doped polypyrrole. J. Power Sources 2008, 177, 665-668. [CrossRef]

17. Yurum, Y.; Taralp, A.; Veziroglu, T.N. Storage of hydrogen in nanostructured carbon materials. Int. J. Hydrogen Energy 2009, 34, 3784-3798. [CrossRef]

18. Czerwinski, A.; Zelazowska, M. Electrochemical behavior of lead dioxide deposited on reticulated vitreous carbon (RVC). J. Power Sources 1997, 64, 29-34. [CrossRef]

19. Pec, M.K.; Reyes, R.; Sajnchez, E.; Carballar, D.; Delgado, A.; Santamar, J.; Arruebo, M.; Evora, C. Reticulated vitreous carbon: A useful material for cell adhesion and tissue invasion. Eur. Cell Mater. 2010, 20, 282-294. [CrossRef] [PubMed]

20. Friedrich, J.M.; Ponce-de-León, C.; Reade, G.W.; Walsh, F.C. Reticulated vitreous carbon as an electrode material. J. Electroanal. Chem. 2004, 561, 203-217. [CrossRef]

21. Shui, X.; Chung, D.D.L. High-strength high-surface-area porous carbon made from submicron-diameter carbon filaments. Carbon 1996, 34, 811-814. [CrossRef]

22. Łukaszewski, M.; Żurowski, A.; Czerwiński, A. Hydrogen in thin Pd-based layers deposited on reticulated vitreous carbon-A new system for electrochemical capacitors. J. Power Sources 2008, 185, 1598-1604. [CrossRef]

23. Tangirala, R.; Low, C.T.J.; Ponce-De-Lean, C.; Campbell, S.A.; Walsh, F.C. Copper deposition at segmented, reticulated vitreous carbon cathode in Hull cell. Trans. Inst. Met. Finish. 2010, 88, 84-92. [CrossRef]

24. Saleh, M.M.; Weidlich, C.; Mangold, K.M.; Jattner, K. Absorption/desorption of calcium ions on polypyrrole-loaded reticulated vitreous carbon. J. Appl. Electrochem. 2006, 36, 179-186. [CrossRef]

25. Yuan, Y.; Kim, S. Polypyrrole-coated reticulated vitreous carbon as anode in microbial fuel cell for higher energy output. Bull. Korean Chem. Soc. 2008, 29, 168-172.

26. Dalmolin, C.; Biaggio, S.R.; Rocha-Filho, R.C.; Bocchi, N. Reticulated vitreous carbon/polypyrrole composites as electrodes for lithium batteries: Preparation, electrochemical characterization and charge-discharge performance. Synth. Met. 2010, 160, 173-179. [CrossRef]

27. Dalmolin, C.; Biaggio, S.R.; Rocha-Filho, R.C.; Bocchi, N. Preparation, electrochemical characterization and charge-discharge of reticulated vitreous carbon/polyaniline composite electrodes. Electrochim. Acta 2009, 55, 227-233. [CrossRef]

28. Frydrychewicz, A.; Vassiliev, S.Y.; Tsirlina, G.A.; Jackowska, K. Reticulated vitreous carbon-polyanilinepalladium composite electrodes. Electrochim. Acta 2005, 50, 1885-1893. [CrossRef]

29. Ryu, K.S.; Lee, Y.-G.; Hong, Y.-S.; Park, Y.J.; Wu, X.; Kim, K.M.; Kang, M.G.; Park, N.-G.; Chang, S.H. Poly(ethylenedioxythiophene) (PEDOT) as polymer electrode in redox supercapacitor. Electrochim. Acta 2004, 50, 843-847. [CrossRef]

30. Laforgue, A. All-textile flexible supercapacitors using electrospun poly(3,4-ethylenedioxythiophene) nanofibers. J. Power Sources 2011, 196, 559-564. [CrossRef]

31. Lei, C.; Wilson, P.; Lekakou, C. Effect of poly(3,4-ethylenedioxythiophene) (PEDOT) in carbon-based composite electrodes for electrochemical supercapacitors. J. Power Sources 2011, 196, 7823-7827. [CrossRef]

32. Kelly, T.L.; Yano, K.; Wolf, M.O. Supercapacitive Properties of PEDOT and Carbon Colloidal Microspheres. ACS Appl. Mater. Interfaces 2009, 1, 2536-2543. [CrossRef] [PubMed]

33. Coffey, B.; Madsen, P.V.; Poehler, T.O.; Searson, P.C. High Charge Density Conducting Polymer/Graphite Fiber Composite Electrodes for Battery Applications. J. Electrochem. Soc. 1995, 142, 321-325. [CrossRef]

34. Dalmolin, C.; Canobre, S.C.; Biaggio, S.R.; Rocha-Filho, R.C.; Bocchi, N. Electropolymerization of polyaniline on high surface area carbon substrates. J. Electroanal. Chem. 2005, 578, 9-15. [CrossRef]

35. Iroh, J.O.; Wood, G.A. Physical and chemical properties of polypyrrole-carbon fiber interphases formed by aqueous electrosynthesis. J. Appl. Polym. Sci. 1996, 62, 1761-1769. [CrossRef]

36. Shedge, H.Y. Specific and Non-Specific Binding of Proteins and Nucleic Acids on Chemically Modified Reticulated Vitreous Carbon Electrodes. Available online: http:/ / tigerprints.clemson.edu/cgi/viewcontent. cgi?article=1545\&context $=$ all_theses (accessed on 21 July 2017).

37. Otero, T.F.; Romero, M.C. Conformational energy from the oxidation kinetics of poly(3,4-ethylenedioxythiophene) films. Polym. Int. 2010, 59, 329-336. [CrossRef] 
38. Seshadri, V.; Wu, L.; Sotzing, G.A. Conjugated Polymers via Electrochemical Polymerization of Thieno[3,4-b]thiophene (T34bT) and 3,4-Ethylenedioxythiophene (EDOT). Langmuir 2003, 19, 9479-9485. [CrossRef]

39. Jung, H.-H.; Hwang, S.-W.; Hyun, S.-H.; Lee, K.-H.; Kim, G.-T. Capacitive deionization characteristics of nanostructured carbon aerogel electrodes synthesized via ambient drying. Desalination 2007, 216, 377-385. [CrossRef]

40. Pekala, R.W.; Farmer, J.C.; Alviso, C.T.; Tran, T.D.; Mayer, S.T.; Miller, J.M.; Dunn, B. Carbon aerogels for electrochemical applications. J. Non-Cryst. Solids 1998, 225, 74-80. [CrossRef]

41. Oren, Y. Capacitive deionization (CDI) for desalination and water treatment past, present and future (a review). Desalination 2008, 228, 10-29. [CrossRef]

42. Biesheuvel, P.M. Thermodynamic cycle analysis for capacitive deionization. J. Colloid Interface Sci. 2009, 332, 258-264. [CrossRef] [PubMed]

43. Choi, J.-H. Fabrication of a carbon electrode using activated carbon powder and application to the capacitive deionization process. Sep. Purif. Technol. 2010, 70, 362-366. [CrossRef]

44. Aldalbahi, A.; Rahaman, M.; Almoiqli, M. A Strategy to Enhance the Electrode Performance of Novel Three-Dimensional PEDOT/RVC Composites by Electrochemical Deposition Method. Polymers 2017, 9, 157. [CrossRef]

45. Li, H.; Zou, L.; Pan, L.; Sun, Z. Using graphene nano-flakes as electrodes to remove ferric ions by capacitive deionization. Sep. Purif. Technol. 2010, 75, 8-14. [CrossRef]

46. Li, H.; Zou, L.; Pan, L.; Sun, Z. Novel Graphene-Like Electrodes for Capacitive Deionization. Environ. Sci. Technol. 2010, 44, 8692-8697. [CrossRef] [PubMed]

47. Chen, Z.; Song, C.; Sun, X.; Guo, H.; Zhu, G. Kinetic and isotherm studies on the electrosorption of $\mathrm{NaCl}$ from aqueous solutions by activated carbon electrodes. Desalination 2011, 267, 239-243. [CrossRef]

48. Wang, Z.; Dou, B.; Zheng, L.; Zhang, G.; Liu, Z.; Hao, Z. Effective desalination by capacitive deionization with functional graphene nanocomposite as novel electrode material. Desalination 2012, 299, 96-102. [CrossRef]

49. Wang, G.; Pan, C.; Wang, L.; Dong, Q.; Yu, C.; Zhao, Z.; Qiu, J. Activated carbon nanofiber webs made by electrospinning for capacitive deionization. Electrochim. Acta 2012, 69, 65-70. [CrossRef]

50. Peng, Z.; Zhang, D.; Shi, L.; Yan, T. High performance ordered mesoporous carbon/carbon nanotube composite electrodes for capacitive deionization. J. Mater. Chem. 2012, 22, 6603-6612. [CrossRef]

51. Nie, C.; Pan, L.; Li, H.; Chen, T.; Lu, T.; Sun, Z. Electrophoretic deposition of carbon nanotubes film electrodes for capacitive deionization. J. Electroanal. Chem. 2012, 666, 85-88. [CrossRef]

52. Hou, C.-H.; Huang, J.-F.; Lin, H.-R.; Wang, B.-Y. Preparation of activated carbon sheet electrode assisted electrosorption process. J. Taiwan Inst. Chem. Eng. 2012, 43, 473-479. [CrossRef]

53. Villar, I.; Suarez-De La Calle, D.J.; González, Z.; Granda, M.; Blanco, C.; Menéndez, R.; Santamaría, R. Carbon materials as electrodes for electrosorption of $\mathrm{NaCl}$ in aqueous solutions. Adsorption 2011, 17, 467-471. [CrossRef]

54. Li, H.; Pan, L.; Zhang, Y.; Zou, L.; Sun, C.; Zhan, Y.; Sun, Z. Kinetics and thermodynamics study for electrosorption of $\mathrm{NaCl}$ onto carbon nanotubes and carbon nanofibers electrodes. Chem. Phys. Lett. 2010, 485, 161-166. [CrossRef]

55. Purdom, P.W. Environmental Health, 2nd ed.; Academic Press: New York, NY, USA, 1980.

56. Marichev, V.A. Partial charge transfer during anion adsorption: Methodological aspects. Surf. Sci. Rep. 2005, 56, 277-324. [CrossRef]

(C) 2017 by the authors. Licensee MDPI, Basel, Switzerland. This article is an open access article distributed under the terms and conditions of the Creative Commons Attribution (CC BY) license (http:/ / creativecommons.org/licenses/by/4.0/). 